\title{
ARISTOTLE IN HELl AND AQUiNAS IN HEAVEN: HUGO DE NOVOCASTRO, OFM AND DURANDUS DE AURELIACO, OP
}

For the history of Aristotelianism, the question "Utrum Aristoteles sit salvatus" has long played an exemplary role. Since Martin Grabmann first drew attention to the question, its consignment of the Philosopher to eternal flames has represented one end of the spectrum of judgments on Aristotle, the counterweight to Dante's situating him in Limbo and Lambert de Monte's argument for his salvation. ${ }^{1}$ It has also served as the representative of a silent majority, to the point of being called even "a genre of quodlibetal questions" in which, confronted with the question of Aristotle's salvation, "most conservative theologians packed him off to hell.",

Two major factors have limited the ability of historians to gauge the impact of this question: it is isolated and anonymous. It exists in a single manuscript, Città del Vaticano, BAV, Cod. Vat. lat. 1012, as one of the final questions in a miscellany containing predominantly Franciscan questions mostly from the $1310 \mathrm{~s}$ and $20 \mathrm{~s}$, some of them from written quodlibeta. The question lacks any ascription of author, and so its appearance in the codex means that it might be a quodlibetal determination, and it probably is by a Franciscan. ${ }^{3}$

${ }^{1}$ M. GRABMANN, “Aristoteles im Werturteil des Mittelalters”, in Mittelalterliches Geistesleben: Abhandlungen zur Geschichte der Scholastik und Mystik 3, München 1936, 63-102; A.-H. Chroust, "A Contribution to the Medieval Discussion: 'Utrum Aristoteles Sit Salvatus"”, in Journal of the History of Ideas 6 (1945), 231-38; R. IMBACH, "Aristoteles in der Hölle. Eine anonyme Questio 'Utrum Aristotiles sit salvatus' im Cod. Vat. Lat. 1012 (127ra127va) zum Jenseitsschicksal des Stagiriten", in Peregrina Curiositas: Eine Reise durch den orbis antiquus, hrsg. v. A. Kessler, T. Ricklin und G. Wurst, Freiburg (Schweiz) 1994, 297-318 (containing the edition); IDEM, "De salute Aristotilis. Fussnote zu einem scheinbar nebensächlichen Thema”, in Contemplata aliis tradere. Studien zum Verhältnis von Literatur und Spiritualität, hrsg. v. C. Brinker, U. Herzog, N. LARgier und P. Michel, Bern 1995, 157-73; S. NeGRI, "La quaestio «De salvatione Aristotelis» del tomista Lamberto di Monte", in L'antichità classica nel pensiero medievale, a cura di A. PALAzzo, Porto 2011, 413-40; Peter von Moos, Heiden im Himmel? Geschichte einer Aporie zwischen Mittelalter und Früher Neuzeit, Heidelberg 2014.

${ }^{2}$ K. Robertson, “Abusing Aristotle”, in Speculative Medievalisms: Discography, ed. E. JoY, A. KŁosowska, N. Masciandaro and M. O’RourKe, Brooklyn, NY 2013, 159-72, here 161.

${ }^{3}$ On Cod. Vat. lat. 1012, see W.O. DuBA, "Continental Franciscan Quodlibeta after Scotus”, in Theological Quodlibeta in the Middle Ages: The Fourteenth Century, ed. C. SCHABEL (Brill's Companions to the Christian Tradition 7), Leiden-Boston 2007, 569-649, here 640-49. 
While working on a study of the eternity of the world in fourteenthcentury Franciscan thought, I found strong parallels between the Franciscan theologian Hugh of Neufchâteau's (Hugo de Novocastro) commentary on the Sentences, likely deriving from lectures given at Paris in the first half of the 1310 s, and the question on Aristotle's fate. ${ }^{4}$ Specifically, two of the three arguments in the question find parallels in Hugh of Neufchâteau's commentary on Book II d.1 of the Sentences q.4, "Utrum aeternitas mundi secundum quod eam ponit Aristoteles possit demonstrari esse impossibilis," and the damning conclusion corresponds, in part word-for-word, to a passage in the commentary. In the question on the salvation of Aristotle, the author makes three claims: first, that Christian beatitude cannot be known from pure natural capacities alone; second, that the Secreta secretorum and the Liber de pomo, which imply Aristotle's salvation, are not authentic works; ${ }^{6}$ third, that Aristotle's philosophy is incompatible with Christian beatitude, and that, if he had some revelation that made his salvation possible, we would at least have heard about his change of mind. The first claim matches Hugh of Neufchâteau's thesis in q.4: natural reason is insufficient to demonstrate the eternity or temporal creation of the world. Although Hugh's question in the Sentences does not discuss the authority of the Liber de pomo or the Secreta secretorum, its presentation of Aristotle's doctrine of the soul matches that used in support of the third claim in the anonymous question on salvation. Specifically, the third claim holds that Aristotle's teaching about the soul is incompatible with Christian belief; because, on the one hand, Aristotle posited an eternal world, and, on the other, that an actual infinite cannot exist, he had either to posit that there is only one, incorruptible soul for all humanity or that the soul is corrupted with the body, but what he actually held is in doubt. $^{7}$ Similarly, Hugh concludes that what Aristotle actually said about

\footnotetext{
${ }^{4}$ On Hugh of Neufchâteau, see W.J. CourTEnAY, "Early Scotists at Paris: A Reconsideration", in Franciscan Studies 69 (2011), 175-225, at 207-9.

${ }^{5}$ In what follows, I use the copies contained in Firenze, Biblioteca Nazionale Centrale, Cod. Conv. Soppr. A.3.641, ff. 7va-9ra (=J); Tortosa, Archivio Capitular, Cód. 201, ff. 8va$10 \mathrm{rb}(=\mathrm{T})$, checked against Paris, BnF, Ms. lat. 15856, ff. 22ra-23rb (=Y), which presents an earlier redaction of the question.

${ }^{6}$ This particular aspect is analyzed in S.J. WiLliams, The Secret of Secrets: The Scholarly Career of a Pseudo-Aristotelian Text in the Latin Middle Ages, Ann Arbor, MI 2003, 276-79.

7 "Utrum Aristotelis sit salvatus", ed. in IMBACH, "Aristoteles in der Hölle", 309. This analysis of Aristotle's true doctrine of the soul has precedents in HENRICUS OF GANDAVO, Quodlibet IX q. 14, and Bonaventura (a Bagnorea), In II Sent. d.1 pars 1 q.2; for Henry, see K. Emery, Jr., "The Image of God, Deep in the Mind: the Continuity of Cognition according to Henry of Ghent", in Nach der Verurteilung von 1277: Philosophie und Theologie an der Universität von Paris im letzten Viertel des 13. Jahrhunderts. Studien und Texte, hrsg. v. J.A. Aertsen, K. Emery, Jr. und A. Speer (Miscellanea Mediaevalia 28), Berlin
} 
human souls is uncertain, and many think that Aristotle would hold "the opinion of the Commentator" (that a single intellect is eternal); for his part, Hugh believes that "the intellect by which we formally understand is not an incorruptible form."

Finally, the conclusion of the question on salvation, in which the author places Aristotle in Hell, has verbatim parallels with Hugh's refutation of the preliminary argument that Aristotle did not believe that he had demonstrated the eternity of the world. Both texts use the same passage from Augustine to put Aristotle in Hell, making the same adjustments to:

Augustinus exponens illud Psalmi Absorpti sunt iuncti petre iudices eorum, videtur expresse dicere quod ipse est dampnatus in inferno, ubi comparatur Petrae, id est Christus, contremiscit. ${ }^{9}$

Finally, both texts make the same observation, practically word-for-word, on the need for circumspection when discussing the truths of faith:

\begin{tabular}{|c|c|}
\hline H, “Aristoteles in der Hölle”, & ) \\
\hline $\begin{array}{l}\text { urali- } \\
\text { quo- } \\
\text { reve- } \\
\text { rentie }\end{array}$ & $\begin{array}{l}\text { etiam fecit in hiis quae ratione } \\
\text { investigari possunt. In hiis autem } \\
\text { veritas sciri non potest nisi ex rez } \\
\text { defecit nimis [J 9ra] superbe adhaere } \\
\text { rentiae suae rationis. Scivit enim, et } \\
\text { bus quorum fides dicit oppositum, }\end{array}$ \\
\hline
\end{tabular}

2001, 59-124, at 95-98; for Bonaventure see R.C. DALES, Medieval Discussions of the Eternity of the World, Leiden 1990, 94.

${ }^{8}$ Hugo de Novocastro, In II Sent. d.1 q.4 (J, f. 8rb; T, f. 9va): “Ad tertiam rationem de animabus dicitur quod nescitur determinate quid diceret. Videtur enim multis quod ipse teneret opinionem Commentatoris, sed mihi hoc non videtur possibile, cum evidenter includat contradictoria ut ostendetur infra. Credo ergo omnibus praetermissis quod secundum sua principia ipse diceret quod intellectus quo intelligimus formaliter non est forma incorruptibilis, licet continuationem habeat cum intelligentia aliqua incorruptibili."

9 "Utrum Aristotelis sit salvatus", ed. in IMBACH, "Aristoteles in der Hölle", 309-10; Hugo De Novocastro, In II Sent. d.1 q.4 (J, f. 9ra; T, f. 10rb). Cf. Augustinus HiPponensis, Enarrationes in Psalmos: CI-CL (CCSL 40), on Ps. 140, 2040: "Quid faciunt pauci aliter disputantes? Iudices sunt impiorum. Sed quid ad te? Vide quid sequitur: absorpti sunt iuxta petram iudices eorum. Quid est: absorpti sunt iuxta petram? Petra autem erat Christus. Absorpti sunt iuxta petram. Iuxta, id est, comparati iudices, magni, potentes, docti; ipsi dicuntur iudices eorum, tamquam iudicantes de moribus et sententiam proferentes. Dixit hoc Aristoteles. Adiunge illum petrae, et absorptus est. Quis est Aristoteles? Audiat: dixit Christus, et apud inferos contremiscit." 
remote sunt a sensibus, falsa esse probabiliora veris et talia excedere mentem hominis. Et per consequens de talibus nihil proterve nec superbe debuit assere. bus quae remota sunt a sensibus, quaedam falsa esse probabiliora quibusdam veris et talia excedere mentem hominis, et per consequens in talibus nihil proterve nec superbe debuit asserere.

The question "Utrum Aristoteles sit salvatus" should therefore be ascribed to Hugh of Neufchâteau. Moreover, Hugh's commentary on the Sentences repeats the same claims about Aristotle's salvation, and unlike his question, the commentary survives in numerous copies across Europe, and had an influence on medieval thought that, if not known, is at least capable of investigation.

\section{Inevidentiae contra Durandum de Aureliaco}

As the question "Utrum Aristoteles sit salvatus" for Aristotelianism, so the Evidentiae contra Durandum has served as a landmark for Thomism. Isabel Iribarren has underscored that the author of the Evidentiae used the text of Thomas to criticize Durand rather than defend the ideas of Thomas against criticism, which marks a development in the history of Thomism:

Whereas Hervaeus' Thomism showed the resilience of times of controversy, the Thomist elements in the Evidentiae are presented in a way more suitable for commentary than interpretation. Durandellus makes a normative use of the Thomist corpus, as he adduces quotations from Aquinas' works for the sake of proof in his arguments against Durand. The value of the Evidentiae thus resides in its being probably the first example we possess of Aquinas' writings being treated as a locus theologicus, as obliged theological reference. ${ }^{10}$

When Joseph Koch studied the Evidentiae in 1927, its author, known as 'Durandellus', was generally assumed to be the Dominican theologian Durand of Aurillac:

The usual view is that Durandus de Aureliaco is Durandellus. Since he read the Sentences in 1330-31 and in [1334] as a Master of Theology participated in the controversy over the beatific vision, the fact that Thomas in the Evidentiae is called sanctus poses no problems regarding his authorship. Accordingly, the younger Durandus could very well be the author of the Evidentiae. In addition, this is supported by the fact that in Cod. 198 of the library of the University of Paris, on f. 150r, one reads: Incipit prohemium Durandi. Therefore, the question needs closer examination. ${ }^{11}$

\footnotetext{
10 I. Iribarren, "Thomism", in Encyclopedia of Medieval Philosophy. Philosophy between 500 and 1500, ed. H. LAGERLUND, Dordrecht 2011, 1302-8, at 1305-6.

${ }^{11}$ J. Koch, Durandus de S. Porciano O.P. Forschungen zum Streit um Thomas von Aquin zu Beginn des 14. Jahrhunderts (Beiträge zur Geschichte der Philosophie des Mittelalters
} 
Koch diligently studied the only surviving written work positively ascribed to Durand of Aurillac, the question "Utrum tempus sit aliquid reale extra animam," preserved in a single manuscript copy, El Escorial, Biblioteca del Real Monasterio de San Lorenzo, Cód. lat. R.II.4, ff. 145va-147vb. On this basis, Koch rejected the identification of Durand of Aurillac with Durandellus. To find the author, Koch first determined that the author wrote after Thomas' canonization in 1325 and, at least at the time of writing, was not a master of theology. He then followed his hunches: several early copies of Durandellus came from Italy, and a thematic resonance suggested someone from the circle of John of Naples. In two manuscripts, Koch found an attribution to a certain Nicolaus, although in one case, this attribution is based on a misreading. ${ }^{12}$ The other manuscript is in Naples, and begins: "Incipiunt soluciones, responsiones et reprobaciones racionum et opposicionum domini Durandi, que fecit contra sanctum Thomam, fratris Nicolai Medensis." ${ }^{.13}$ Koch therefore proposed a certain Nicholas of S. Vittore, a Dominican who attended the 1344 General Chapter of Le Puy as the definitor of the province of the Kingdom of Sicily. Koch concludes: "In any case, one should follow this trail further, starting with a more precise investigation into Ms. VII C 51 in Naples. Only archival research in situ can cast light on the question.,"14

Following Koch's lead, the editor of the Evidentiae, P.T. Stella, suggested that this Nicholas could come from a house of Benedictine women named S. Vittore in the town of Meda near Milan. ${ }^{15}$ Further, he judged that the Naples manuscript was a fragmentary and contaminated witness of the Evidentiae. ${ }^{16}$

While I have not yet had the opportunity to examine the Naples manu-

26), Münster i.W. 1927, 359-60: "Die gewöhnliche Ansicht geht dahin, daß Durandus de Aureliaco $=$ Durandellus ist. Da er 1330/31 die Sentenzen gelesen und 1332 als Magister am Streit um die visio beatifica teilgenommen hat, so macht bei ihm der Umstand, daß Thomas in den evidentiae als sanctus bezeichnet wird, keine Schwierigkeiten. Außerdem spricht viels dafür, daß die evidentiae um 1330 entstanden sind. Demnach könnte der jüngere Durandus recht wohl der Verfasser der evidentiae sein. Hinzu kommt, daß in Cod. 198 der Pariser Universitätsbibliothek f. 150r zu lesen ist: Incipit prohemium Durandi. Die Frage bedarf also genauer Prüfung."

12 A. MAIER, "Zur Textüberlieferung einiger Gutachten des Johannes de Neapoli”, in Ausgehendes Mittelalter. Gesammelte Aufsätze zur Geistegeschichte des 14. Jahrhunderts, Roma 1977, 481-504, here 504.

13 Nicolai Medensis (Durandelli) Evidentiae contra Durandum, 2 vols., ed. P.T. Stella, Tübingen 2003, in vol. 1, 62*; cf. Koch, Durandus de S. Porciano O.P., 368, who reads quas facit instead of Stella's que fecit.

${ }^{14} \mathrm{Koch}$, Durandus de S. Porciano O.P.,365-69.

${ }^{15}$ Durandellus, Evidentiae 1, ed. Stella, $21 *$.

${ }^{16}$ Durandellus, Evidentiae 1, ed. Stella, 191*. 
script, I can put forth a better case for the identity of Durandellus without besmirching the honor of the nuns of S. Vittore: Durand of Aurillac. Koch's refutation of the identity between Durand of Aurillac and Durandellus is in itself insufficient. Moreover, the close textual parallels between the question on time used by Koch and Walter Burley's commentary on the Physics show that Durand of Aurillac's question either derives from some version of Burley's commentary, or that both come from an earlier source. Finally, Durand of Aurillac's Franciscan contemporary, William of Brienne, explicitly and implicitly criticizes him in a way that evokes parallels with Durandellus' doctrine.

Koch makes three arguments to dissociate Durandellus from Durand of Aurillac on the basis of the latter's question on time. First, in this question, Durand of Aurillac criticizes Peter Auriol, Robert Grosseteste and even Hervaeus Natalis, but he does not mention Durand of Saint-Pourçain's unique view, which Durandellus ought to have done. Second, this question shows a great interest for what Koch calls "mathematical-physical questions (tempus, motus, continuum, etc.)," for which Durandellus seems to have little interest in his Evidentiae. Finally, Koch identifies a doctrinal contradiction. In his question on time, Durand of Aurillac states that there is nothing intrinsic in every motion such that 'being-caused-by-theheavens' pertains to its essence ("unus enim motus non est de essencia alterius"). Rather, this causality is due to the current order of the universe. On the other hand, Durandellus, concerning the punishment of the damned, argues that "what is prior by nature and as a cause is not prior in a certain respect, say according to the present order, but without restriction." Durand of Aurillac seems to say that being caused is extrinsic to what a thing is, while Durandellus holds that a prior, causal motion is included in every terrestrial motion. ${ }^{17}$

Neither of the first two arguments, based on negative evidence, suffices to establish real non-identity. Only the third argument seems strong. Durandellus, as will be discussed below, famously holds that a relation has no reality outside of its foundation and term; on this assumption, then, a relation of causality would have no reality outside of its terms, and being prior by nature would be identical with (and rationally distinct from) the cause, the heavens, and extrinsic to the caused, terrestrial motion. Thus the apparent contradiction disappears.

Durand of Aurillac's question on time, moreover, shows a strong association with Walter Burley's commentary on the Physics, to the point that it ap-

\footnotetext{
${ }^{17}$ Koch, Durandus de S. Porciano O.P., 363-64.
} 
pears to be a paraphrase of his Questions on the Physics IV tr.3 cc.1-2. Durand's question follows the structure of Burley's commentary, and at times carries verbatim the same text, such as the discussion of the senses of time:

Gualterus Burlaeus, In IV Physicorum tr.3 c.2 (Venezia 1501, f. 131vb; Venezia 1589, col. 536)

Maxime vero proprie accipitur tempus pro duratione primi mobilis, quia motus primi mobilis est primus inter omnes motus et maxime uniformis. Et ille sunt condiciones essentiales motus quem tempus primo consequitur. Motus etiam primi mobilis est velocissimus, et ideo maxime habet rationem mensure, quoniam illa duratio primi mobilis est primum tempus, sicut motus primi mobilis est primus inter omnes motus.
Durandus de Aureliaco, Quaestio de tempore, El Escorial, Biblioteca del Real Monasterio de San Lorenzo, Cód. lat. R.II.4, f. 146ra

Quinto, maxime proprie accipitur pro duracione motus primi mobilis, qui est primus inter omnes et maxime uniformis. Et iste sunt condiciones essentiales motus quem tempus consequitur. Et ille motus est velocissimus. Unde duratio successiva istius motus vere et proprie dicitur tempus.

The "contradictory" passage that Koch identified parallels Burley somewhat more freely:

\begin{tabular}{|l|l|}
\hline $\begin{array}{l}\text { GUALTERUS BURLAEUS, In IV Physicorum tr.3 c.2 } \\
\text { (Venezia 1501, f. 132va-vb; Venezia 1589, col. } \\
\text { 539) }\end{array}$ & $\begin{array}{l}\text { DURANDUS DE AURELIACO, Quaestio de } \\
\text { tempore, El Escorial, Biblioteca del } \\
\text { Real Monasterio de San Lorenzo, Cód. } \\
\text { lat. R.II.4, f. 146va }\end{array}$ \\
\hline $\begin{array}{l}\text { Et, si dicitur quod Commentator dicit quod, si } \\
\text { celum staret, nos non essemus in esse trans- } \\
\text { mutabili, quod tamen non sequitur, si stante celo, } \\
\text { posset esse aliquis alius motus, unde secundum } \\
\text { Commentatorem sequitur: 'non est motus celi, } \\
\text { ergo nullus alius motus', } \\
\text { Physicorum quod, posito quod primum } \\
\text { mobile staret, pariter (scripsit Koch) } \\
\text { omnis alius motus, et per consequens } \\
\text { non esset aliquo modo tempus. }\end{array}$ \\
$\begin{array}{l}\text { dicendum quod non sequitur per consequentiam } \\
\text { tenentem per locum intrinsecum 'motus celi non } \\
\text { est, ergo nullus alius motus est', sicut etiam non } \\
\text { sequitur econverso per locum intrinsecum 'alius } \\
\text { motus est a motu celi, ergo motus celi est et ita ad } \\
\text { illam celum stat'. Non sequitur quod nullus mo- } \\
\text { tus est tanquam aliquid quod est de intellectu } \\
\text { antecedentis. }\end{array}$ & $\begin{array}{l}\text { Sed quia consequentia sua non tenet ab } \\
\text { essentia alterius quin uno existente, ali- } \\
\text { us possit non esse - }\end{array}$ \\
\hline $\begin{array}{l}\text { Attamen sequitur per locum extrinsecum, non } \\
\text { sequitur ratione ordinis naturalis universi, quo- } \\
\text { niam secundum ordinem naturalem universi qui- } \\
\text { libet alius motus dependet in esse a primo motu. }\end{array}$ & $\begin{array}{l}\text { sed tenet ab extrinseco, considerato or- } \\
\text { dine universi qui nunc est, ideo dicendo } \\
\text { aliter, scilicet quod, cessante motu pri- } \\
\text { mi mobilis, et remanente motu alterius } \\
\text { mobilis, non esset tempus propriissime } \\
\text { dictum; esset tamen aliud tempus quod } \\
\text { esset duratio illius motus. }\end{array}$ \\
& \\
\hline
\end{tabular}


While the exact connection between the Quaestio de tempore and the various redactions of Burley's work needs further analysis, the link suffices to explain (against Koch) why Durand of Aurillac appears so interested in the physical part of the topic, and not the metaphysical aspects, and why he does not mention Durand of Saint-Pourçain: his source is a Physics commentary that does not mention Durand either. Like Durandellus in the Evidentiae, Durand of Aurillac here applies a text in front of him to resolve a problem.

Finally, Durand of Aurillac's Franciscan contemporary who read the Sentences at Paris in the same academic year (1330-31), William of Brienne, explicitly associates with his adversaries doctrines characteristic of Durandellus. Specifically, two studies of Durandellus published in 1997 identify two points at which Durandellus' doctrine in the Evidentiae breaks with the teaching of Thomas. First, Gilles Emery shows that Durandellus repeatedly insists that a relation has no reality apart from those of its foundation and its term, and that a relation is distinguished from its foundation only by reason. ${ }^{18}$ Second, Henry Donneaud accuses Durandellus of a serious confusion in epistemology when he departs from Thomas' teaching on faith; in particular, while Thomas denies that one can have faith and scientific knowledge of the same conclusion, since faith is based on the conclusion's inevidence and knowledge on its evidence, he does allow that one can both believe and know a given conclusion. Durandellus also denies that properly speaking faith and scientific knowledge can be had of the same object, but, according to Donneaud, he mixes up the medium that causes assent (demonstration in scientific knowledge and authority in faith) with the (in)evidence of the conclusion. Therefore faith and belief on authority become co-extensive, and one cannot believe a conclusion known demonstratively. ${ }^{19}$ Donneaud concludes: "A direct consequence of this reductionist interpretation consists in the impossibility for the Christian philosopher to continue to rely on the authority of revelation from the moment that he

\footnotetext{
${ }^{18}$ G. EMERY, "La théologie trinitaire des Evidentiae contra Durandum de Durandellus", in Revue Thomiste 97 (1997), 173-218, here 182-88.

${ }^{19}$ H. Donneaud, "Durand et Durandellus sur les rapports de la foi et de la science", in Revue Thomiste 97 (1997), 157-72, here 163: "Or Durandellus confond lui aussi le plan des médiums et celui du résultat subjectif de la connaissance. Il est vrai que l'inévidence - le moins connu - ne peut pas produire l'évidence - le plus connu. Et une fois que l'évidence est là, l'inévidence, concernant ce même objet, ne peut que disparaître. S'ensuit-il que, dans l'ordre des médiums, la démonstration soit exclusive de l'autorité? L'incompossibilité de l'évidence et de l'inévidence, qualités de l'objet connu, entraîne-t-elle nécessairement celle de l'autorité et de la démonstration? Durandellus l'affirme sans le prouver. Nous verrons même qu'il contredit saint Thomas précisément sur ce point, faute de relever la différence entre l'ordre des médiums et celui de l'objet."
} 


\section{knows demonstratively a revealed truth, such as the existence of God. ${ }^{, 20}$}

Durandellus seems to have been aware of an objection like that of Donneaud, and in a passage that escaped Donneaud's notice, he refers to "scientific knowledge a posteriori, which perhaps is not incompatible with faith." 21 To save his epistemology, Durandellus does not reconcile belief with demonstration but rather faith with scientific knowledge, conceding some type of scientific knowledge is compatible with faith, and that this knowledge is $a$ posteriori. An example of such a posteriori demonstration is God's unity.

\section{Traces of these innovations can be found in parts of William of}

${ }^{20}$ IDEM, Ibid., 170-71: "Dans sa réfutation de la thèse Durand sur la compatibilité de la science et de la foi, Durandellus s'en tient à la lettre de la thèse thomiste, en effet contraire. Croyant défendre saint Thomas, il outrepasse nettement les positions du maitre. La raison de cette déformation nous a semblé résider dans l'ignorance tant de la raison formelle précise que saint Thomas attribue à la foi que, conséquemment, de la distinction entre l'ordre des médiums et celui de l'objet. Durandellus assigne indifféremment comme raison formelle à la foi tantôt l'inévidence, tantôt l'autorité. Il confond ces deux formalités, en bloquant l'au-torité sur l'inévidence et la démonstration sur l'évidence. Contrairement à saint Thomas, qui situe précisément la raison formelle de la foi dans l'inévidence, Durandellus n'hésite pas à la placer également dans ce médium qu'est l'autorité: « Il est de la définition de la foi de donner assentiment à une conclusion en vertu de l'autorité de celui qui parle. » Parce qu'il semble ignorer la distinction entre les deux ordres, pourtant posée par saint Thomas lui-même, le disciple en vient quasiment à contredire le maître. Il affirme l'impossibilité du concours de ces deux médiums que sont l'autorité et la démonstration au profit d'un unique assentiment: "Personne ne peut donner assentiment à une conclusion en vertu, simultanément, de l'autorité et de la démonstration; non seulement à la cause de l'incompatibilité de deux actes d'intellection en un même intellect, mais aussi à cause d'une autre incompatibilité formelle: celle qui existe entre les deux actes, car la définition de l'un exclut celle de l'autre. » Saint Thomas pose pourtant une affirmation contraire: " le même homme peut connaître une même conclusion par un médium probable et par un médium démonstratif. » Dès cette époque, l'école thomiste n'évite donc pas certaines infidélités par rapport à sa source. Croyant défendre le maître, elle en vient à l'infléchir, par inattention aux nuances de sa pensée. Une conséquence directe de cette interprétation réductrice consiste dans l'im-possibilité, pour le philosophe chrétien, de continuer à s'appuyer sur l'autorité de la révélation dès lors qu'il connaît démonstrativement une vérité révélée, comme l'existence de Dieu."

${ }^{21}$ Durandellus, Evidentiae III.32, ed. Stella, 924: "Quod autem concludit quod scientia quam habemus quod Deus est unus certior est fide qua credimus quod est trinus, dico quod comparando fidem tantum, quae habetur per auctoritatem divinam, ad scientiam humanam, fides semper est certior eo modo quo dictum est. Sed comparando fidem, quae habetur per auctoritatem divinam, et scientiam humana ratione habitam - et hoc loquendo de scientia quae est a posteriori, quae forsitan fidei non repugnat -, comparando igitur ista duo ad fidem tantum, illud quod cognoscimus vel cui assentimus propter ista duo certius est quam illud cui assentimus propter alterum tantum, sicut est in exemplo posito. Fide enim simul et demonstratione a posteriori tenemus quod Deus est unus, sed solum fide tenemus quod est trinus. Secus autem esset, si sola fides ad scientiam humanam comparetur." 
Brienne's commentary related to his principia on the Sentences, specifically when he criticizes his fellow bachelors. In his final principium, on Book III of the Sentences, he refers twice to a socius, that is, to another bachelor reading the Sentences the same year, who holds that relations are not different from their foundation and terms. ${ }^{22}$ One of William's colleagues held exactly the same view as Durandellus.

William of Brienne also explicitly engages Durand of Aurillac on the question of the compatibility of scientific knowledge and faith. In his third lectio on the Sentences, William says that his socius, identified in the margin as Durand of Aurillac, argues against the compatibility of knowledge and faith, saying this that "theology is a science in us, but to us it is not a science, but faith." 23 Because the manuscript containing William of Brienne's testimony is the original reportatio, ${ }^{24}$ we can date his comment precisely: it appears in his third lecture, held at the earliest on 12 October 1330, and in any case not much later. As a bachelor reading the Sentences, William of Brienne was expected to react to the principia of the other bachelors, held in sequence between 14 September and 9 October, starting with the Carmelite, possibly John Vogolon, and ending with the Dominican, Durand of Aurillac. Therefore, William's comment is almost certainly directed at a statement made during Durand's principium question. William then objects that his colleague contradicts himself elsewhere:

But on the other hand, it is said first that his statement contradicts those that he says elsewhere. For he says that theology is cognition in us, but a cognition that is not through the cause. Against this: no cognition is scientific knowledge properly speaking if it is not cognition through the cause; but theology in us is not such a cognition; therefore, etc. But this contradicts his statements, because he says that there is no scientific cognition that does not receive the cause in being, but the minor premise is his own;

${ }^{22}$ Guilelmus de Brena, Principium in III Sent. (Praha, Národní Knihovna České Republiky, Cod. VIII.F.14, f. 141r): "Oppositum: incarnatio-actio est relatio; sed nulla relatio est distincta res a fundamento et termino; ideo etc. Minor per unum socium hoc dicentem."(f. 142r): "Quantum ad secundum articulum, et dixit socius quod nulla relatio est res distincta a fundamento; sed ego dixi oppositum contradictoria(leg. contradictorie?) quod aliqua sit."

${ }^{23}$ Guilelmus de BrenA, Lectio 3 (Praha, NKCR, Cod. VIII.F.14, f. 6v): Sed contra hoc dicit unus socius (in marg: Illa est opinio fratris Turandi, iam legentis sententias apud Predicatores), dicit quod theologia est scientia in nobis, sed non nobis; sed est nobis fides."

${ }^{24}$ For a brief treatment of this manuscript and principia, see W. DuBA, "Rebuilding the Stemma: Understanding the Manuscript Tradition of Francis of Marchia's Commentaries on Book II of the Sentences", in Durand of Saint-Pourçain and his Sentences Commentary: Historical, Philosophical, and Theological Issues, ed. A. SPEER, F. ReTUCCI, T. JESCHKE and G. Guldentops (Recherches de Théologie et Philosophie médiévale 9), Leuven 2014, 119-69, here 140-47. 
for if he says that theology is cognition through the cause, I argue to the contrary: where there is no cognition that is a priori on the part of reality, there is no deduction by the cause; but this is so in theology, therefore, etc. And even he concedes this. ${ }^{25}$

William of Brienne attributes three doctrines to Durand of Aurillac: (1) theology is science in us, but faith to us; (2) scientific cognition is through the cause; (3) theology does not deduce from a prior cause to a posterior effect. From the context, Durand of Aurillac defended the first doctrine (1) in his first principium. He maintained at least one of the other two (2 or 3 ) "elsewhere," alibi, and, since William is referring to alibi in the first week of class, that alibi must precede Durand's Sentential year at Paris, which would match what we know about the Evidentiae. That scientific cognition occurs through the cause (2) could arguably be said to correspond with Durandellus' statements that scientific knowledge is caused by demonstration; the concession that theology does not proceed from prior cause to posterior effect (3) matches Durandellus' admission that theology is scientific cognition a posteriori.

Durandellus famously argued that scientific knowledge is based on evidence and caused by demonstration in a such a way that it excludes faith based on inevidence and caused by authority. The always-hesitant identification of Durandellus with the bastard son of a Lombard nunnery has been based largely on authorities arguing from inevidence. The evidence, however, demonstrates for the most part that Durandellus was indeed Durand of Aurillac. ${ }^{26}$

\title{
William O. DUBA (Nijmegen) \\ Radboud Universiteit Nijmegen w.duba@ftr.ru.nl
}

\begin{abstract}
This notice answers two long-running questions of authorship. The first part of the notice addresses the famous question "Utrum Aristoteles sit salvatus" that survives in the manuscript Città del Vaticano, BAV, Cod. Vat. lat. 1012, a miscellany of primarily Francis-

${ }^{25}$ Guilelmus de BrenA, Lectio 3 (Praha, NKCR, Cod. VIII.F.14, f. 6v) "Sed contra dicitur primo quod suum dictum contradicit hiis que ille alibi dicit. Dicit enim quod theologia etc. lest notitia in nobis que tamen non est per causam/. Contra: Nulla notitia est scientia proprie dicta que non sit notitia per causam; sed theologia in nobis non est talis; ideo etc. Sed hoc contradicit dictis suis, quia dicit quod nulla cognicio scientifica est que non sit acceptiva cause in esse; sed minor est sua; si enim negat dicit quod est per causam, contra: ubi non est notitia \a priori/ ex natura rei, ibi non est deductio per causam; sed ita est in theologia; ideo etc. Et hoc etiam ipse concedit." Corrections indicate adjustments to the text made after the lecture.

${ }^{26}$ I hope to explore these themes further in a forthcoming book on William of Brienne, tentatively titled The Forge of Scotism.
\end{abstract}


can texts. On the basis of contextual, textual and thematic parallels, the authorship of the question should be ascribed to Hugh of Neufchâteau, OFM (fl. 1310s). The second part considers the case of the Evidentiae contra Durandum, whose author, known as Durandellus, Joseph Koch identified with a certain Nicolaus Medensis in 1927. A re-examination of Koch's reasoning makes this attribution doubtful, and the witness of the original Reportatio of William of Brienne, OFM, shows that the Dominican theologian Durand of Aurillac is more likely the author of the Evidentiae.

Keywords: Aristotle, Durand of Aurillac, Durandellus, Hell, Hugh of Neufchâtel, Thomas Aquinas, William of Brienne. 